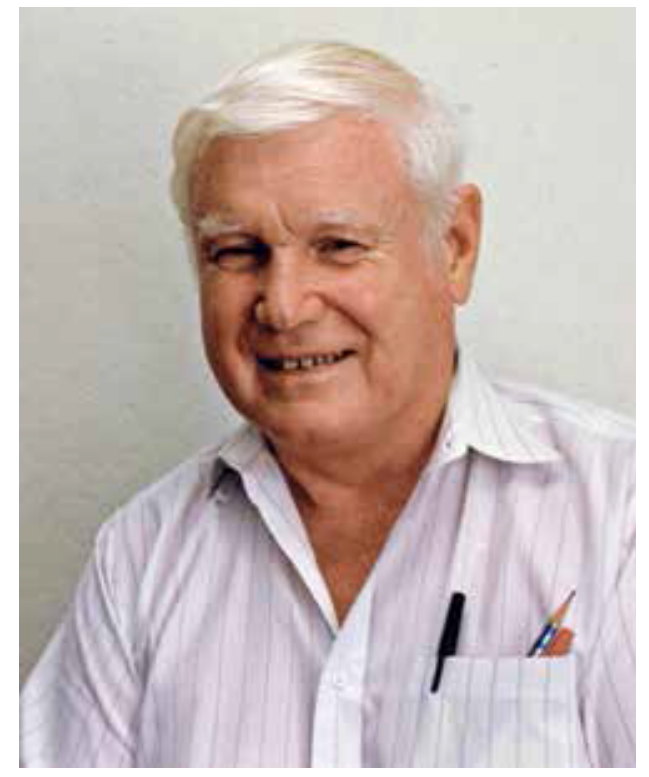

IN MEMORIAM:

\title{
DONALD J. PINKAVA (29 AUGUST 1933-25 JULY 2017)
}

\section{Liz Makings}

\author{
Herbarium (ASU), School of Life Sciences \\ Arizona State University, P.O. Box 874108 \\ Tempe, Arizona 85287-4108, U.S.A. \\ elizabeth.makings@asu.edu
}

My name is Liz Makings and I am the collections manager of the Arizona State University Herbarium. I was a graduate student at ASU in 2000 when I met Dr. Pinkava and he had just retired, so while I missed out on his talents as a teacher, I was lucky to get to know him as a mentor, colleague, and friend.

Dr. Pinkava had a heart of gold, a mind like a trap, and a delightful collection of idiosyncrasies that was perfectly suited to his career path. He was hired at ASU in 1964 after completing his PhD. at Ohio State and was immediately responsible for teaching a 300 level botany class called "Flora of Arizona." He undertook this responsibility with a meticulousness and attention to detail that can only be described as "Pinkavesque," collecting the plants, learning the flora, and scouring the state for the best field trip sites. To his students he was simultaneously feared and adored. His exams turned men into boys and triggered anxiety attacks even among the best. He did not give grades, you earned them. There was no one more demanding, no one more thorough, yet no one more caring and helpful. Many former students have sung his praises and I'll share this quote from one:

"Dr. Pinkava was one of the kindest scientists I have ever interacted with, a trait that sometimes goes missing in our academic world. He was a highly effective teacher; I remember hanging on his every word in Flora of Arizona. He delivered so much content so clearly and deeply. But what I remember most was a brief hallway conversation when I was just starting my ecology studies as a graduate student in the 1980s. At the time, like many other similarly indoctrinated conservation biologists, I was very much in the 
'anti-exotic-species' camp. In the hallway, I asked him about the native or exotic status of a species of grass that grew in the riparian zone I was studying, to which he replied, simply, "What does that matter? A plant is a plant." That response was like a kind slap in the face which reminded me to restore my scientific skepticism and not to blindly accept other people's words. That brief conversation had a profound impact on me."-Dr. Julie Stromberg, Professor, Arizona State University School of Life Sciences

Dr. Pinkava's gentle personality, sage advice, patience, and quiet strength are traits that are consistently and fondly recalled. And when it came to instruction, he didn't just teach classes, he lived them, and devoted an enormous amount of time and energy into his preparation. In addition to Flora, he taught upper division courses in cytogenetics, herbarium techniques, and taxonomy of southwestern desert plants. In "Experimental Plant Systematics" (Botany 598), students were greeted with nine pages of his handwritten notes and diagrams on the first day! Dr. Pinkava's knowledge of the plant world was encyclopedic, gained through decades of hard work-yet it was never about him. He was unassuming and humble, and never made anyone feel beholden. You couldn't ask for a better mentor. Dr. Pinkava began taking on graduate students early in his career and managed them effectively and effortlessly, giving them their autonomy to explore and create, yet being appropriately hands-on when needed. He was so tolerant and open-minded that he probably never took notice of the fact that, in his lab, he had more female graduate students than male, a non-trivial detail during times of gender discrimination, and a trend that continued until he retired. It is also noteworthy that he allowed students to take full credit for their research: about half of the publications resulting from the work of Pinkava graduate students do not have his name as an author.

He was the academic father to many and there is an impressive list of students that paid him the ultimate compliment by going on to important academic and/or applied botanical careers, such as at the University of Alaska, the University of Arkansas, Augusta College in Georgia, Cal Poly San Louis Obispo, Clemson University, the University of Maryland, the University of Michigan Flint, the San Diego Natural History Museum, San Juan College, and the University of Wyoming to mention a few. There are agency scientists in the Forest Service, Bureau of Land Management, Park Service, and local municipalities. There are botanical consultants, administrators, and a superstar entourage at the Desert Botanical Garden in Phoenix. And yes, a fair share of anarchists which he would be equally as proud of.

The reality is, there are untold botanical disciples of Dr. Pinkava who are spreading the gospel of the wonders of the plant world. Their origin stories might trace back to a classroom experience, a mind-blowing field trip, or even an informal encounter that was nevertheless life-changing. His 'amateur botanist' students are no less influential than the pros-heading up local native plants societies, working in herbaria, volunteering in schools and botanical gardens, mentoring, parenting, and most importantly, always teaching.

Pinkava graduate students typically did floristic studies and systematics research, though he has a bookshelf of dissertations and theses from a variety of disciplines-you name it, he supervised it—which also speaks to his personality and acceptance of diversity. He was incredibly proud of his students and bragged about them all the time. He quietly demanded excellence and brought out the best in us with the appropriate amount of constructive criticism and praise. You did not want to disappoint Dr. Pinkava.

As an academic, Dr. Pinkava was first and foremost a teacher, but embraced the reality of pursuing external funding as the university landscape changed. He wrote and received many high profile grants that contributed greatly to the importance and growth of the Herbarium. He was the consummate professional and was revered and loved by colleagues. Revered because of his work ethic and accomplishments, and loved because of his collegial spirit, unselfishly giving of his expertise to anyone who asked. I personally leaned on him constantly for help with prickly pears, chollas, and, frankly, many other plants I struggled to identify, and he always had the answers, or at least put you on the right direction with just the right amount of information. He was a walking Kearney and Peebles ${ }^{1}$.

Dr. Pinkava along with his longtime curator, Elinor Lehto, created a vegetative key to the cultivated plants

${ }^{1}$ Arizona Flora, by T.H. Kearney and R.H. Peebles, University of California Press (1960) 
in the Phoenix area-a one-of-a-kind tome that treated over 375 species (I continue to use it in my teaching today). Since he thrived on tedium and attention to detail, editing was naturally one of his gifts and he spent a lot of herbarium time over a microscope with pencil in hand, working through keys, verifying geographical distributions, correcting nomenclatural errors, and making countless marginal notes for Flora of North America draft manuscripts.

He contributed to some of the most important floristic studies in the southwest and devoted a significant portion of his research life to the Cuatro Cienegas flora in Chihuahua, Mexico. He was one of the founding editors of the Vascular Plants of Arizona project. Pinkava and his students have amassed one of the best collections of Cactaceae in the world, including over 1500 specimens that are vouchered with chromosome counts.

Dr. Pinkava was a note-taking fiend. I have yet to come across reference material in the herbarium lacking his comments and annotations, including a falling-apart yet priceless edition of our Arizona Flora, laced throughout with his beautiful handwriting. Dr. Pinkava was OCD before the phrase was even in the vernacular, and thank goodness for his tendencies because we have many things to show for it - a reprint library with thousands of documents and manuscripts that are not available on the web; a treasury of teaching notes; a priceless collection of textbooks, journals, and rare books; and an herbarium that went from a few thousand specimens in 1964 to over a quarter of a million by the time he retired.

Yes, he was a collector: stamps and birds were major hobbies for him, but his passion was plants. There are many tales of Dr. Pinkava's plant collecting pursuits that need no embellishment to qualify as legendary. He collected everywhere he went from tropical forests to low deserts to alpine tundra, and collected every life form he could find, from submerged aquatics to tree-top epiphytes. And cacti-lots of cacti. Death Valley? Kino Bay? Top of Mount Baldy? Been there, done that, got the herbarium specimen.

Ah, but these are natural areas. That's easy, everybody does that. Dr. Pinkava was the king of unconventional collecting, grabbing plants from everywhere he went: farms, lumberyards, mine tailings, gas stations, and all manner of roadsides. He snuck specimens from botanical gardens, zoos, and arboreta; he took flowers from vases on restaurant tables and centerpieces at weddings; he collected landscape plants from hotel parking lots, private yards, and college campuses; he snatched specimens from rest stops, campgrounds, ruins, irrigation ditches, and even bridges. He would go to nurseries and collect not only the container plants but the weeds that were growing in those containers. He collected in banana plantations, in coffee plantations, canals, quarries, orchards, horse pastures, maintenance yards, and cemeteries. He once collected 26 species while touring on the "Jungle Jim Boat Tour" along Rio San Cristobal in Nayarit, Mexico. I can just picture him, clippers concealed until just the right moment, reaching for that mangrove while the guide wasn't looking. He would purchase a flower arrangement from the local grocery store in order to press the unusual-looking Alstroemeria in the bouquet. He even collected plants on his honeymoon ${ }^{2}$ !

I generated a SEINet map ${ }^{3}$ of his collection sites (which took 49 seconds to load) that bears evidence of his extensive travels in the Southwest-a complete traverse of the Baja and the Mexican mainland, as well as significant collections from California, Colorado, New Mexico Utah, and if Arizona is on your BINGO card, you have a complete blackout.

It is impossible to condense such a remarkable and colorful life of nearly 84 years into a few pages and I don't pretend to know even a fraction of the details. But I am thankful for the privilege of his company during a portion of his herbarium years. He would always be interested in any recent exchange, asking if we'd "gotten any weeds lately?" then he would browse the material and insert his commentary and annotate names when necessary. In many ways, I hung on his every word as well, especially when it came to advice on teaching or when he would try to make me understand why this prickly-pear with the yellow flower and flat, brown spines was an entirely different species from this other prickly-pear with the yellow flower and flat, brown spines.

Mary Pinkava asked me to deliver a eulogy at the funeral services last July. A eulogy, "a speech or piece of

${ }^{2}$ There really are herbarium records from all of the above mentioned places.

${ }^{3}$ SEINet - Arizona Chapter. 2018. http//:swbiodiversity.org/seinet/index.php 
writing that praises someone highly," could have been written by anyone who knew him since praise was a unanimous sentiment for Dr. Pinkava. He was one of those special people that really did seem to get along with everybody, was sincere and generous with all, and had the utmost integrity in everything he did. He was as committed to his family as he was to his botanical community-a devoted husband, father, and grandfather. On the desk where he typed away DOS commands on a ca. 1977 IBM, sat photos of his beloved grandchildren (while the umpteenth" Botanist of the Millennium" plaque was tucked away in boxes). It is a special person who stays married to the same person his whole life and begins and ends his career in the same institution. Dr. Pinkava embodied the very best of what it means to be a family man, colleague, teacher, and mentor.

Dr. Pinkava, Don, Donny, Grandpapa, will be missed, but always close to our hearts. His spirit remains a tangible presence in the herbarium and his legacy will be honored at the dedication of the "Donald J. Pinkava Herbarium" planned for fall 2018.

\section{Dr. Pinkava selected personal tributes:}

"I worked in the ASU herbarium for about 28 years as the Curator of the Vascular Plant Collection. For most of that time Don was the Director of the herbarium, and technically I think he was my boss, but curiously we never talked about that. We were just colleagues that worked together. All of us who have known Don Pinkava for so many years are saddened by his passing. He was so important to many of us- the "wise mentor" for so many students and associates like me. Don and I worked together on various projects, many of which I never could have done or would not have tried to do alone. We were co-editors of the Journal of the Arizona-Nevada Academy of Science for several years. We were members of the Editorial board of the Vascular Plants of Arizona Project. We were co-chairs for several graduate students. We wrote grant proposals together and even got funded sometimes.

"Don loved to work in the herbarium. When a new shipment of plants would come in as a gift or exchange, he would sit at a table and take a look at every specimen and perhaps comment on what a nice addition to the herbarium it was going to make.

"He enjoyed filing away newly mounted specimens. I offered to do that kind of work when I arrived (some people find it a little tedious), but he usually preferred to do it himself, probably because he wanted to see every new specimen again and perhaps correct a misidentification.

"One of the best times of every day was when we would all sit down to lunch and talk over what we were doing, or talk about some unusual or rare plant. The students would often ask questions that only he could answer. Sometimes I would announce that I had found some unusual plant, and it would turn out that the first Curator, Elinor Lehto, and Don's first student, had found it years ago in the same place!

"We would often talk about current events in the University or in the nation, but would try to end lunch on a positive note if we could. We learned to not talk about the various candidates for President during elections, because we soon learned we usually disagreed about that.

"We will all miss his companionship, collaborative spirit, and good advice."

—Les Landrum, Curator Emeritus, Arizona State University Herbarium

"Mary and I were very pleased to hear from Don a few months ago. He was someone very special in both of our lives (and was at our wedding in Tempe), and we'll miss knowing that he is no longer holding forth at ASU."

-Tom Daniel, Curator of Botany, Emeritus California Academy of Sciences

"I still haven't gotten used to not seeing Don traipsing about ASU campus from tree to tree with undergraduates in tow. He will be much missed even though his presence will endure."

—David E. Brown, retired Arizona Game and Fish/adjunct faculty Arizona State University School of Life Sciences

"He was a great botanist who inspired so many of us. And a gentle soul; he always made us feel better. We went on two memorable field trips to Sonora with him. One to visit Sam Friedman's Master's thesis study area in 
coastal thornscrub near Las Bocas and one to the manglares of Naopatia during the massive redo of Gentry's Río Mayo Plants project led by Paul Martin. When we were working on the flora of the Municipio de Yécora in the Sierra Madre Occidental of eastern Sonora, we took the cactus A-team to sort out the opuntias: Dr. Pinkava, Jon Rebman, and Andrew Salywon (a choya guy with more hair before the mustards caught his attention). The floristic contributions to the flora of Arizona by Dr. Pinkava and his stable of Masters students roaming the mountains are the foundations of our knowledge of the flora of Central Arizona. His spirit will always be in the ASU Herbarium. In his younger days, he joined Wendell Minckley in exploring Cuatro Ciénegas, Coahuila, one of the great hot spots of evolution. On a recent pilgrimage (that kind of place) to Cuatro Ciénegas we saw Cylindropuntia anteojoensis described by Pinkava. This scruffy diamond cholla along with the Chihuahuan fringed-toed lizards (Uma exsul and U. paraphygas) are biogeographic marvels of North America. We also saw the newly-described Ancistrocactus pinkavana. He will be missed!"

-Tom and Ana Lilia Van Devender, Madrean Discovery Expeditions, The GreaterGood.org

"This is a great loss. It's hard to imagine not seeing Dr. Pinkava around the herbarium but a great privilege to have been one of his graduate students."

—John Anderson, retired Arizona State botanist, Bureau of Land Management

"Se ha ido una gran persona y botánico del desierto sonorense!!!!!! Un abrazo a todos."

—Jose Delgadillo Rodríguez, Universidad Autónoma de Baja California

"No words can express loss of so wonderful a person—generous, kind, sharing, helpful to all. A privilege to have known him."

—Richard Felger, Associated Researcher, University of Arizona Herbarium, School of Plant Sciences, University of Arizona

"I join you in mourning for his passing. I never met the man, but his many, many courtesies to Bruce Parfitt will not be forgotten in Oshkosh, you may be sure. When Bruce visited here, during his time at ASU, he always spoke so highly of his major professor."

—Neil A. Harriman, Curator Emeritus, University of Wisconsin Oshkosh Herbarium

"I wish I had taken more photos of him looking through the presses that students took out of the drier. I will never ever forget how he was like someone opening a Christmas present when he encouraged his students to show him what they had dragged in. He was always delighted—he loved surprises."

—Dixie Damrel, Curator, Clemson University Herbarium

"I wish I had taken more photos of him looking through the presses that students took out of the drier. I will never ever forget how he was like someone opening a Christmas present when he encouraged his students to show him what they had dragged in. He was always delighted—he loved surprises."

"I am so fortunate to have been able to witness his passion and knowledge over the many conversations we had. He lives on, even in those of us who had the fortune of interacting with him at the tail end of his career."

-Frankie Coburn, former graduate student

"I wish I had taken more photos of him looking through the presses that students took out of the drier. I will never ever forget how he was like someone opening a Christmas present when he encouraged his students to show him what they had dragged in. He was always delighted—he loved surprises."

"I have many memories of field trips with him, first to Baja when the road stopped about 100 miles S of Ensenada. We got Montezuma's revenge the first day out. Got some of my first lichens and Don collected many 
samples for cytological investigations. Particularly memorable was a long trip through the Chihuahuan Desert including Quatro Cienegas. We had major challenges trying to dry the plants (presses mounted on the roof as we drove down the highways). Particularly memorable was waking up one morning shortly after the plant presses around the fire had burned up, including what would have been a type!"

-Thomas Nash III, University of Wisconsin Senior Scientist, Arizona State University Emeritus Professor

"Dr. Pinkava was a brilliant cytogeneticist and taxonomist. He was the quintessential student of the Cactaceae who did not yield to popular thought without the rigor of hard evidence. He was indefatigable in his pursuit of knowledge and had a limitless capacity for literature and an unflagging research ethic. He is loved by his colleagues and a myriad of undergraduate and graduate students, many of whom regard him as their academic father, who was and, in spirit, still is ever demanding excellence."

-Marc Baker, Southwest Botanical Research, former graduate student, adjunct, Arizona State University

"How would I describe Don Pinkava to someone who is not a botanist? Maybe as the Dr. Doolittle of the plant world! I met Don when I came to ASU as a new faculty member, just coming from our shared alma mater, The Ohio State University. An amorphous time when one feels neither fish nor fowl, with a brand new degree and the "right" to call a colleague "Don," but still used to referring to a gentleman a couple of decades older than myself as "Dr Pinkava." And he was always both to me. Warm friendship and decent, honorable, respectable in the best sense of the word.

"Some snapshots:

"Seventy miles an hour across western AZ watching the landscape change from saguaros to Joshua trees and back again, naming every tiny yellow flower-blur as we flew by. An avid birder, Don could see things invisible to a normal eye. Playing "petals 5, carpels 2, grows on ASU campus" with Don and Les and watching them both crinkle their eyes at some of the combinations I came up with that didn't exist in this particular world.

"You could see that expression in his eye, looking at a pile of herbarium sheets with a student or a visitor and then looking inward to his encyclopedic memory for the identification, location, habitat, chromosome number. It was obvious that Don knew every plant in Arizona personally, and had history with them. When Steffi (Steffi Ickert-Bond, Professor, University of Alaska) decided to stay at ASU to study Ephedra, this was the right call.

"A presentation with Opuntia hybrids where he would designate them 'Mom' and 'Dad' and 'Baby."'

"The Christmas party at Don's house, when Michelle was still a little girl with the Santa Claus hat, and his students from all over came for a good visit or sent warm wishes and there he was, proud father of them all.

"Don taught me 3 things about students that are a part of my mantra. And his advice is the type of gift that keeps on giving for a lucky colleague, for a career:

1. Every student is different.

2. Every teacher has a style that works for them: so be yourself, and

3. Just give them a tank of gas and a jar of peanut butter and send them out to learn the plants on their own.

Advice doesn't get any better than that."

—Kathleen Pigg, Professor, Arizona State University School of Life Sciences

"I did not know him well; I should have as I took his position line and he was still active for many years following retirement. But I admired his work and was amazed by the number of students that he mentored and graduated over so many years. To me, Don was a lot like Milt Summerfield—a truly dedicated and accomplished scientist, devoted teacher, and a well-liked mentor-who spent their entire careers at ASU. Both had a great sense of humor, too. Their impact on plant biology here (on the former department and the people who made it up) was significant and far reaching (but perhaps a bit under appreciated)."

—Marty Wojcieckowski, Associate Dean and Associate Professor, Arizona State University School of Life Sciences 
"As a graduate student of Dr. Pinkava, I have lots of memories of him-and all of them are good. All of his former students love him and respect him for being a great mentor and a kind, thoughtful, and generous person. I'll just share a couple of memories that come to mind.

The great part about being a graduate student of Dr. Pinkava was the camaraderie that I remember in the herbarium. Without fail, Drs. Pinkava and Landrum and all the graduate students ate lunch together every day and we had a great time. While many other graduate students complained that they rarely talked to their advisors, those of us in the herbarium always had a great relationship with Dr. Pinkava. He was always genuinely concerned about our well-being and, while he mentored us to advance our scientific careers, he also cared and wanted to know about our lives outside of botany as well. I fondly remember the hours we all spent together in good conversation and the wonderful Christmas parties that Dr. and Mrs. Pinkava held where current and former students felt like family.

"Dr. Pinkava loved bird watching and he and I would sometimes go to Gilbert ponds on Saturdays. He always kept a list of all the birds that we saw on small pieces of paper. One time he heard from Audubon bird sightings that there was a blue-footed booby in the east valley. We spent all morning and afternoon driving from Gilbert to Cave Creek looking in all the ponds we could find to see if we could not spot the bird. We had a great time even though we never found the blue-footed booby. I was reminded of how much Dr. Pinkava loved birding when we went on a trip to look at prickly pears of Sonora, Mexico with Tom Van Devender, Ana Lilia Reina, and Jon Rebman. I remember that he was just as excited about seeing new birds as he was in seeing the flora of Sonora. He kept a bird list on this trip, too, and he always had his binoculars with him at all times.

"To know that all my peers respect Dr. Pinkava so highly as a scientist, mentor, and person is a reflection on the type of man he was. We will all miss him dearly, but carry on with the work that he so inspired us to do."

-Andrew Salywon, Assistant Herbarium Curator and Research Botanist, Desert Botanical Garden

"Dr. Pinkava changed my life in several ways... In the mid 80s I wrote a 200 page paper on the prickly pears and chollas of San Luis Potosi, Mexico as my undergrad thesis. I spent several years collecting and ID'ing and numerous times trying to ID specimens. I remember clearly that almost every reference for Opuntia mentioned Donald Pinkava. "Here is a person I would like to meet some day."

"After finishing that paper, instead of being satisfied, I felt somewhat confused and never quite sure about the ID of many of my specimens. I learned later on that this feeling is shared by most of the people that work with Opuntia; including Dr. Pinkava. Prickly pears make you humble....

"Later on, I became one of Dr. Pinkava's students at ASU and that was a great pleasure, learning from him in and outside the classroom and lab. I always enjoyed the many conversations about plants with other students, but my favorite was to talk about prickly pears and chollas. Dr. Pinkava was always game for lengthy conversations on this subject....

"I learned a great deal from Dr. Pinkava, not only about plants, botany and chromosomes, but also about life, friendship and family. I will remember Dr. Pinkava every time I hear the noise produced by a prickly pear spine when flicked by my fingers, as he used to do...."

—Raul Puente-Martinez, Curator of Living Collections, Research Botanist, Desert Botanical Garden

\section{The Legend of Dr. Pink'va by seven anonymous students, sung to the tune of The Legend of Davie Crock- ett at his retirement:}

Born in a little house in '33

In the state of the Buckeye Tree

From the time he was in short pants

He always knew that he loved plants

Dr., Dr. Pink'va, King of the plant ID'ers 
He kilt his first plant when he's only 3

Ma found it, you could hear'r scream

She came out'a there with glochids in 'r hair

Yellin "li'l Donnie, you oughta kill a bear"

Dr., Dr. Pink'va, doin' Biology

I wish that I could tell you 'bout his teenage years

But that's not meant for tender ears

When he got to college he was emphatic

about the subject of systematics

Dr., Dr. Pink'va, an undergrad was he

During the days of his Masters Degree

The Ohio State University

There he let his genius gel

and did a flora near an artesian well

Dr., Dr. Pink'va, collectin' near Sandusky

He decided he would get his PhD

Spent his time working on a DYC

The rays are fertile and the disks are sterile

A native flower called Berlandiera

Dr., Dr. Pink'va, knows his Asteraceae!

In '64 he went down to ASU

It just seemed like the thing to do

Out in the desert he did tromp

Workin on cacti instead of comps

Dr., Dr. Pink'va, workin' with old Sparky

From Arizona down to Mexico with a rest

Studying Opuntia was his quest

Chihuahuan Desert and the southwest

Solving the Opuntia taxonomic mess!

Dr., Dr. Pink'va, best glochid plucker ever be

He studied chromosomes at metaphase

Cactus have eleven as the base

Polyploids, donuts, figure eights

Promiscuous Opuntia be not afraid

Dr., Dr. Pink'va sometimes n=3

His list of publications grew to be enormous

Working on Opuntia engelmanni linguiformis

And flexospina \& lindheimeri

More plants are comin'up, let's give it another try

Don't be afraid of Latin, nobody says it right

Cirsium coahuilense, Flaveria macdouglii

Mimosa unipinnata, Phacelia marshalljohnstonii

Opuntia anteojoensis, Opuntia aureispina

and the new Cylindropuntia $\times$ campii

Dr., Dr. Pinkava, workin' like a bee 
Even after all his taxonomic deeds

He still makes time to look at all our weeds

He'll sit through your e-tire press

You better know your plants, cause he won't let you guess!

Dr., Dr. Pink'va, can't 'scape his scrutiny

No class harder could you find

Than the flora of this state divine

First test made ever'body cry

But they knew their plants by the second try

He-ey Dr. "P" King of the Flora A-Z

Now his plans are the biggest, his plans are the best

From the Cactus Room to a little bird's nest

He will attend the annual Stamp-fest

From teaching, classes he'll finally rest.

Dr., Dr. Pink'va, now he's a retiree-Yipee! 